\title{
THE ROLE OF CLIMATE AND HYDROLOGICAL ELEMENTS IN THE PRODUCTION AND PERSISTENCE OF EXCESS WATER IN THE PLAIN OF SOMEȘ
}

\author{
D. SANISLAI ${ }^{1}$, R. BATTINAŞ ${ }^{2}$, GH. ȘERBAN ${ }^{2}$
}

\begin{abstract}
The role of climate and hydrological elements in the production and persistence of excess water in the Plain of Someș. In determining water excess in the Plain of Somes, we analysed the triggering factors which are directly involved in the formation of the risk phenomenon and which are considered to be the dynamic factors. Of major importance in deciphering the causality of the water surplus are the triggering elements, especially the climatic ones (the rainfall regime), and depending on them to a great extent - the hydrological ones (water resources, drainage). It can be argued that in the last decade, the biggest problems were created especially by small basins and small watercourses, which due to the changes in the precipitation regime (large intensities on small surfaces) had caused many floods, destruction of human settlements, roads and bridges, and had favored the triggering of landslides and implicitly the excess of soil water. The analysis of the natural hazards, implicitly of the water excess, was primarily aimed at meeting the requirements of the elaboration of the landscaping and urbanization plans of the Plain of Someş, according to the legislation and norms in force.
\end{abstract}

Key words: meteorological stations, precipitation, hydrometric stations, hydrographic network, drainage.

\section{INTRODUCTION}

Of major importance in deciphering the causality of the water surplus are the triggering elements, especially the climatic ones (the rainfall regime), and depending on them to a great extent - the hydrological ones (water resources, drainage).

The analysis of the factors, mainly the rainwater and thermal regime should be viewed globally, in the context of global climate changes, and in particular in local conditions specific to the plain under study.

The climatic conditions and the rainfall regime of the Plain of Somes are determined by its geographic position in the northwest of the country, subject to more humid air advection and the particularities of the active surface, amongst which the landform, through exhibition, slope and hypsometry, play a dominant role.

\footnotetext{
1 "Vasile Goldiş" Western University, Faculty of Economics, Computer Science and Engineering, 310414 Arad, Romania, e-mail: sanislaidaniel@yahoo.com

2 "Babeş-Bolyai" University, Faculty of Geography, 400006 Cluj-Napoca, Romania, e-mail: razvan.batinas@ubbcluj.ro gheorghe.serban@ubbcluj.ro
} 
Depending on the geological formation, the paleogeographic conditions dictated by the sedimentation of the Pannonian Basin and the formation of the volcanic landforms, the hydrographic network and groundwater have specific characteristics.

The surface of the Plain of Somes is crossed by a network of natural and anthropogenic courses, resulting from the paleohidrographic evolution, plus spontaneous or systematic human intervention through land improvements (canals, gullies, land drainage, polders, etc.).

\section{SPATIO-TEMPORAL ANALYSIS}

2.1. The climate of the plain is generated by three main categories of factors: radiative, dynamic and physico-geographic ones. All of these have a direct influence on the spatio-temporal variation of climate elements on this plain.

For the climatological analysis carried out in order to establish the main climatic parameters which directly influence the formation of the water surplus, more precisely the rainfall, we used observation data from 24 sampling and processing points of the meteorological data across the Plain of Somes (Fig. 1). However, only eleven of them underwent a more complex analysis, taking into consideration the 26-year common operating period, with complete data strings from 1979 to 2004, so that it would be much more relevant.

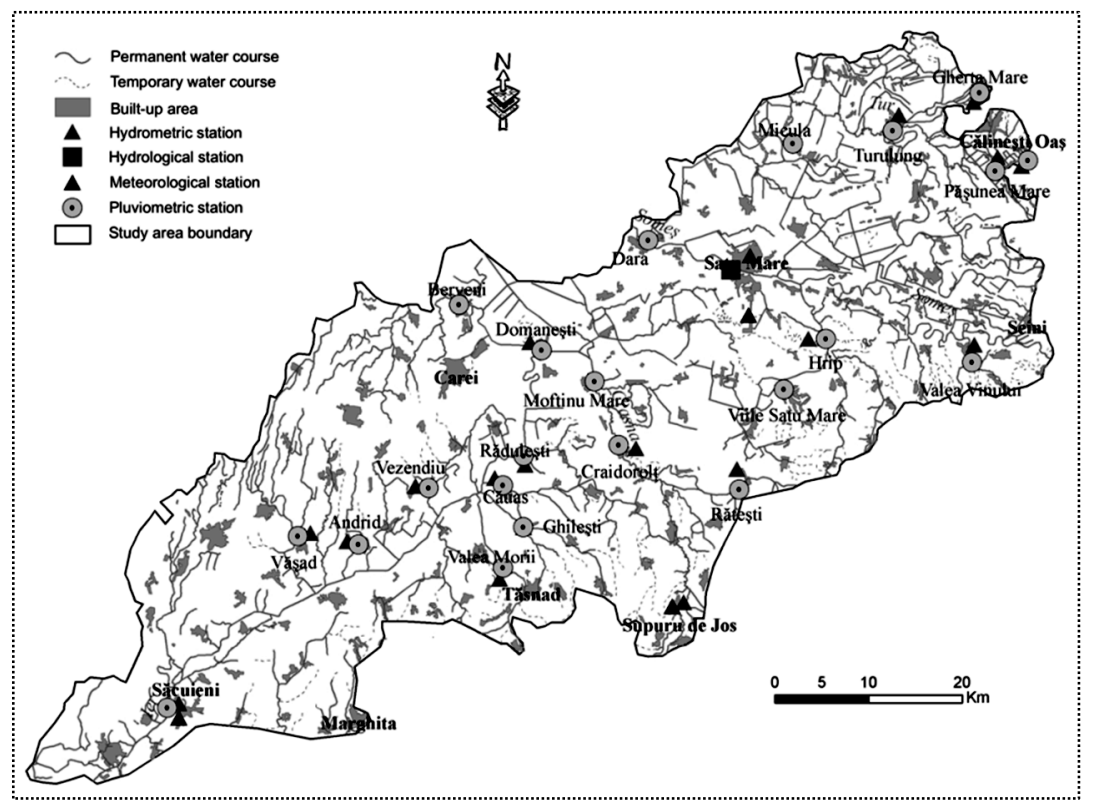

Fig. 1. Locating the sampling points of hydrological and meteorological data from the Plain of Somes 
Regarding the rainfall regime of the Plain of Somes, it is worth mentioning that the precipitation can oscillate between $400 \mathrm{~mm}$ in the dry years and over 1000 $\mathrm{mm}$ in the rainy ones, and monthly, a maximum precipitation occurred in 10-13 May 1970 when the amount of precipitations reached $100 \mathrm{l} / \mathrm{m}^{2}$ in a single day, which normally corresponds to 2-3 months of Carpathian spring.

The genesis of atmospheric precipitation is determined by the frontal activity; frontal rain is the most frequent precipitation type in the region, however, convectional rainfall can also occur at the bottom of the Oaş Basin. A basic feature of precipitations is the large amount of water that falls, even on the lowest slope of the plain, of course, with some regional differentiation due to its position in the North and North-East of the Oas and Ignis Mountains.

The maximum annual precipitation amounts sometimes exceed $800 \mathrm{~mm} /$ year in the eastern part of the Plain of Somes, at its contact with the highest landform units in its vicinity (Table 1).

Table 1. The maximum annual and daily rainfall amount in the Plain of Someş

\begin{tabular}{|c|c|c|c|c|c|c|c|c|c|c|}
\hline \multirow{2}{*}{$\begin{array}{c}\text { Gauging } \\
\text { station }\end{array}$} & \multicolumn{5}{|c|}{ Annual amount pp. (Mm / year) } & \multicolumn{5}{|c|}{ Annual daily maximum pp. (mm) } \\
\hline & \multicolumn{5}{|c|}{ Registration Year } & \multicolumn{5}{|c|}{ Registration date and year } \\
\hline \multirow{2}{*}{$\begin{array}{l}\text { Păşunea } \\
\text { Mare }\end{array}$} & 151.5 & 1102.5 & 1034.3 & 988.8 & 951.4 & 70 & 58.1 & 57.9 & 54.3 & 52.3 \\
\hline & 2001 & 1998 & 5 & 19 & 1999 & 19.10 & $\begin{array}{c}28.06 \\
1982\end{array}$ & 30.09 & $\begin{array}{l}09.06 \\
1990\end{array}$ & $\begin{array}{l}14.07 \\
1989\end{array}$ \\
\hline \multirow[b]{2}{*}{$\begin{array}{l}\text { Gherța } \\
\text { Mare }\end{array}$} & 991.9 & 974.8 & 6.1 & & & 77.8 & & 59 & & 54.4 \\
\hline & 1998 & 1980 & 2001 & 1979 & 1981 & $\begin{array}{l}30.09 \\
1992 \\
\end{array}$ & & $\begin{array}{l}02.08 \\
1991 \\
\end{array}$ & & $\begin{array}{r}22.07 \\
1980 \\
\end{array}$ \\
\hline \multirow[b]{2}{*}{ Turulung } & 920.5 & 879.4 & 0521 & 809.4 & 801.1 & $\begin{array}{ll}69.8 \\
\end{array}$ & 56.3 & 48.7 & 46.3 & 44.6 \\
\hline & 1980 & & & 8 & 1995 & $\begin{array}{l}01.08 \\
1991 \\
\end{array}$ & & & & $\begin{array}{l}25.03 \\
2004 \\
\end{array}$ \\
\hline \multirow[b]{2}{*}{$\begin{array}{l}\text { Valea } \\
\text { Vinului }\end{array}$} & 1058.0 & 1009.4 & & 8 & 853.1 & 88. & & 56 & & 54.2 \\
\hline & 01 & 1998 & & & 2004 & $\begin{array}{l}04.10 \\
2003\end{array}$ & & & & $\begin{array}{l}25.03 \\
2004\end{array}$ \\
\hline \multirow[b]{2}{*}{ Hrip } & 876.5 & 788.5 & 100.0 & 767.3 & 759.5 & 72.1 & & & & 62.8 \\
\hline & & & & & 99 & & & & & \\
\hline \multirow[b]{2}{*}{ Satu Mare } & 808.7 & 807.5 & 779 & 68 & 645.7 & 59.5 & 57. & 48 & 44.6 & 44.3 \\
\hline & & & & & & $\begin{array}{c}22.07 \\
1993\end{array}$ & $\begin{array}{l}13.07 \\
1989\end{array}$ & & $\begin{array}{l}17.10 \\
2004\end{array}$ & $\begin{array}{l}19.10 \\
1996\end{array}$ \\
\hline \multirow[b]{2}{*}{ Berveni } & 07.5 & & & 545.5 & 503.4 & 68 & & & & .1 \\
\hline & & & & 1999 & 03 & $\begin{array}{l}04.07 \\
2001 \\
\end{array}$ & & & & $\begin{array}{l}24.05 \\
1996 \\
\end{array}$ \\
\hline \multirow[b]{2}{*}{ Domănești } & 775.7 & 73 & 70 & 639.1 & 633.6 & 69.0 & 62 & 58 & 54.7 & 52.3 \\
\hline & & & & & & $\begin{array}{c}24.06 \\
1989\end{array}$ & & & & $\begin{array}{l}12.09 \\
1995\end{array}$ \\
\hline \multirow[b]{2}{*}{$\begin{array}{l}\text { Supuru de } \\
\text { Jos }\end{array}$} & 841.0 & 625.7 & 6 & 606.7 & 591.5 & 62.7 & 62.3 & 62.1 & 60.7 & 58.9 \\
\hline & & & & & & $\begin{array}{l}30.07 \\
2003\end{array}$ & $\begin{array}{c}28.07 \\
1991\end{array}$ & $\begin{array}{l}19.06 \\
1993\end{array}$ & $\begin{array}{c}16.04 \\
1998\end{array}$ & $\begin{array}{l}23.06 \\
1996\end{array}$ \\
\hline \multirow[b]{2}{*}{ Valea Morii } & 838.3 & 787.1 & 785.3 & 727.6 & 715.8 & 67.4 & 57. & 56 & 55.7 & 55.0 \\
\hline & & & & 1989 & 1996 & $\begin{array}{l}13.07 \\
2003 \\
\end{array}$ & $\begin{array}{l}30.07 \\
1980 \\
\end{array}$ & $\begin{array}{l}17.05 \\
1985 \\
\end{array}$ & $\begin{array}{l}20.06 \\
1995 \\
\end{array}$ & $\begin{array}{l}12.07 \\
1981 \\
\end{array}$ \\
\hline \multirow[b]{2}{*}{ Săcuier } & 776.1 & 737.2 & 711.9 & 689.0 & 686.3 & 88.9 & 54.9 & 53.1 & 52.2 & 51.1 \\
\hline & 1980 & 2001 & 1998 & 1979 & 2004 & $\begin{array}{l}12.09 \\
2001\end{array}$ & $\begin{array}{c}28.07 \\
1998\end{array}$ & $\begin{array}{l}08.08 \\
1979 \\
\end{array}$ & $\begin{array}{l}17.06 \\
1983 \\
\end{array}$ & $\begin{array}{l}13.07 \\
1981 \\
\end{array}$ \\
\hline
\end{tabular}


Thus, at Păşunea Mare and Gherţa Mare rainfall stations, from the hydrographic sub-basin of Tur, at the foot of the Oaş and Igniş Mountains, where the air masses are forced to escalate the higher landforms, the upward movement contributes to the intensification of the nebulosity on the slopes exposed to the air masses, so that rainfall is generated. The annual precipitation amounts exceed 800 $\mathrm{mm}$, with a maximum annual sum of $1151 \mathrm{~mm}$ in 2001 for the former rainfall station and $991.9 \mathrm{~mm}$ in 1998 for the latter. Also in the sub-basin of Tur, at the Turulung rainfall station, the annual maximum amount of $920.5 \mathrm{~mm}$ was registered in 1980 .

The same situation is also found in the North-Western part of the Codru Peak, at Valea Vinului rainfall station, where the maximum annual amount was also registered in 2001 reaching the value of $1058 \mathrm{~mm}$.

The maximum monthly quantities recorded during the respective period were $88.9 \mathrm{~mm}$ in Săcuieni on 12/09/2001, $88.0 \mathrm{~mm}$ in Valea Vinului on 04/10/2003, $77.8 \mathrm{~mm}$ in Gherţa Mare on 30/09/1992 and $72.1 \mathrm{~mm}$ at the Hrip rainfall station on 12/08/1984 (Table 1).

Analyzing the dynamics of the annual rainfall amounts at the meteorological stations and rainfall stations mentioned above, for the common period of 26 years, from 1979 to 2004, it is noticed that the most rainy years in the Plain of Somes were the following: 1979, 1980 , 1998, 1999 and 2001, when cyclonic activity persisted, many years registering values above $800 \mathrm{~mm}$, at most of the rainfall stations, when the air temperature increased, amplifying the thermal convection of the air.

\subsection{The hydrographic network and groundwater accumulation and circulation conditions}

As mentioned above, as regards the water resource as a triggering factor in the determination of the water surplus, the following aspects were considered: surface water through (multiannual average drainage, maximum recorded flows), groundwater and deep confined waterbed.

\subsubsection{Organization and morphometric features of the hydrographic network}

The surface of the Plain of Somes is crossed by a network of natural and anthropogenic courses, resulting from the paleohidrographic evolution, plus spontaneous or systematic human intervention through land improvements (canals, gullies, land drainage, polders, etc.).

In the analysis of the morphometric parameters were used the observations data from 9 hydrometric stations, on complete datasets (26 years), from 1979 to 2004, controlling hydrographical basins whose altitude oscillates between $251 \mathrm{~m}$ and $534 \mathrm{~m}$, and the area between $69 \mathrm{~km}^{2}$ and 15,600 $\mathrm{km}^{2}$ (Table 2). 


\subsubsection{Rivers and lakes systems}

The river network of the studied region attracted by one of the maximum sinking areas of the Plain of Tisa comprises a total of 107 coded water courses with a total length of $1487.5 \mathrm{~km}$ belonging to two large water catchment areas: SomeşTisa (Tur, Homorod and Crasna) and Crişuri (Ier) (Fig. 2).

Table 2. The hydrometric stations in the Plain of Somes

\begin{tabular}{|l|l|c|r|}
\hline \multicolumn{1}{|c|}{ River } & Hydrometric Station & H (m) & F $\mathbf{( k m}^{2} \mathbf{)}$ \\
\hline Tur & Turulung & 366 & 1144 \\
\hline Turț & Gherța Mare & 315 & 74 \\
\hline Talna & Pășunea Mare & 402 & 186 \\
\hline Someș & Satu Mare & 534 & 15600 \\
\hline Valea Vinului & Valea Vinului & 251 & 69 \\
\hline Crasna & Domănești & 261 & 1705 \\
\hline Crasna & Supuru de Jos & 310 & 1170 \\
\hline Santău/Cehal & Valea Morii & 294 & 169 \\
\hline Ier & Săcuieni & 287 & 1392 \\
\hline
\end{tabular}

The rivers from the Plain of Somes now occupy much-diminished areas compared to the past, the current aspect of the hydrographic network being the result of hydrotechnical works. Thus, the course of the rivers was largely regularized, many of the Somes meanders were directed and the smaller rivers were fully channelled.

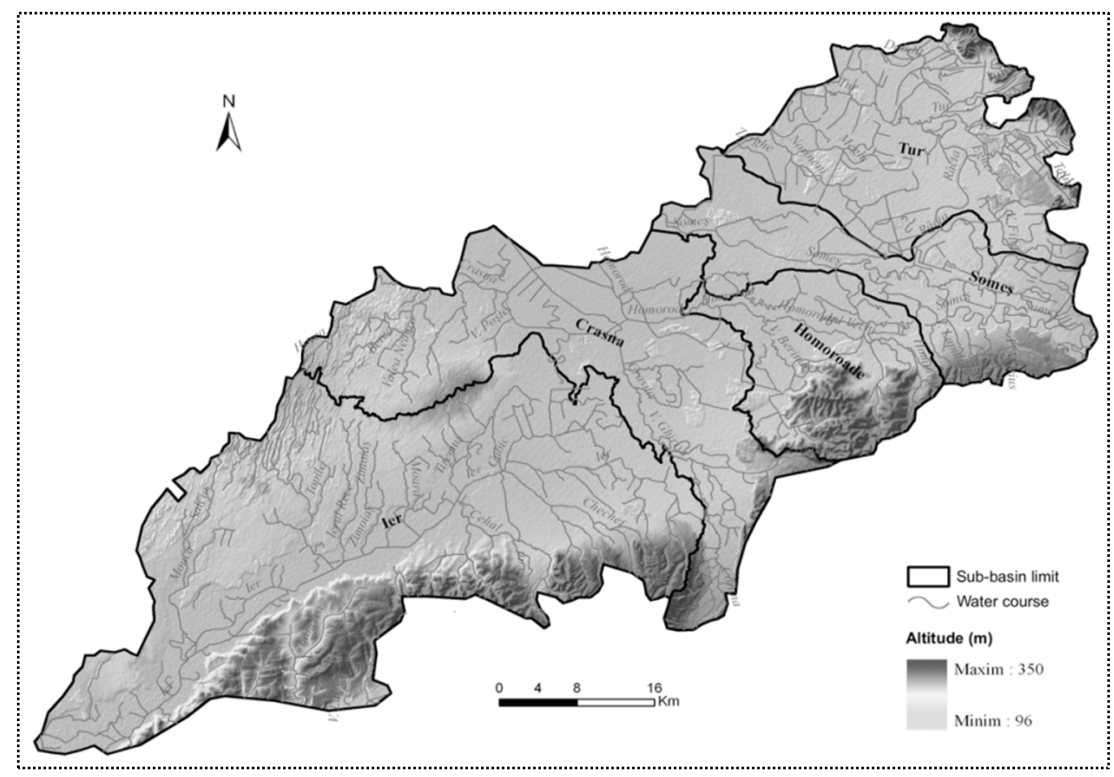

Fig. 2. Sub-basins and the hydrographic network in the Plain of Somes 
Impoundment and draining have also resulted in the emergence of many channels by digging drainage channels.

Stagnant waters in the studied area occupy reduced surfaces following hydroameliorative interventions that required important mutations. Long time ago the lakes, and especially the numerous ponds, related to the extensive marshlands, were one of the dominant elements of the landscape in this part of the country, the most representative being the Ecedea swamp.

At present, in addition to the protected marshland, there are only anthropic lakes, such as ponds and millponds, with small surfaces and few in number. Most of them are retentions on the valleys that come from Carei Plain to Ier (the lakes Andrid-Dindești, Vășad, Galoșpetru, Șimian), rarely the ones on the left side, or the valleys of Sălacea-Roşiori Plain (the lakes Sălacea, Vaida, Ianca, Făncica).

For the Tur River sub-basin, we can mention the accumulations of Bercu Nou (Micula), Adrian (Livada), on the left side of Tur and the Dabolţ pond (Halmeu) on its right side. can be mentioned.

On the site of the old meanders and the deserted courses of the Tur and Somes rivers there are dozens of small-scale lacustral units formed in natural conditions.

\subsubsection{The maximum rivers runoff}

By the weight of the destructive effects and its characteristics (levels, flows, volume, duration, etc.), the maximum drainage is the most important phase of the regime, all the more so since it is directly responsible for determining the water excess.

Following the chronological variation of the maximum annual flows over the 26 years between 1979 and 2004, at all 9 hydrometric stations in the Plain of Somes, it is noted that in the basins of Tur, Gherţa Mare, Păşunea Mare and Turulung, the maximum flow rates were recorded in 1996, 1997 and 2001; in the Somes river basin at Valea Vinului and Satu Mare stations, the maximum flows were recorded in 1980 and 1981; at the Domăneşti and Supuru de Jos hydropower stations from the catchment area of Crasna, the maximum flows were recorded in 1979 for the former case, and 1989 for the latter; the Ier river basin had the maximum flow values in 1980 at the Săcuieni hydrometric station on the Ier river and in 1989 on the Santău River at Valea Morii.

\subsubsection{Groundwater accumulation and movement conditions}

A major role in the water movement is represented by the underground water deposits. The study of groundwater, especially the study of dynamics and their relations with the surface hydrographic network and the local climatic conditions, is necessary for all hydroamelioration works, especially in drainage works. According to the genesis and hydrogeological storage conditions, groundwater is divided into deep water and subsoil water. The geology of the sedimentary deposits in the Plain 
of Somes subbasement has determined a diverse range of hydrogeological conditions.

In the Subsoil of the Plain of Somes there have accumulated a thick stack of different structures with a whole range of hydrogeological conditions. Depending on these conditions, two environments can be distinguished: a deep one and another one closer to the surface. Of greater interest is the layer close to the surface comprised during new formations, especially the Pleistocene and Holocene, which are represented by an alternation of pebbles, clays, loamy sands, sandy clays, loess, slimes etc., which contribute directly to the determination of the excess water..

In exceptional cases of extremely high precipitation, such as those in 1970, 1975, 1980 and 2001, the blue sand layer could not capture all the precipitation water, thus the surplus water passed into the covering layers. In such situations, water appears on the surface, defending the processes of pouring and even engraving.

Depending on the hydrogeological factors that generated them, the groundwaters of the Somes Plain are divided into two main categories: surface waters (with no hydrostatic pressure), located in the active area in terms of hydrological balance, and depth waters.

Surface groundwaters may be: surface groundwaters, which occur in the aeration area during periods of high moisture, especially in the spring, and are of a temporary nature; groundwater and descendant captives, formed in the upper loose layers, are of a permanent nature and are influenced by lithological and climatic conditions; stratification or lenticular waters with no hydrostatic pressure, found in places with alternating structure of permeable (sands) and impermeable layers (clays). These waters can be found in the lower parts of subsidence of the Plain (Lower Somes Plain), with a slow or no leakage at depths varying between 0.5 and $3.0 \mathrm{~m}$, causing saltiness of the area (Moftin and Sânmiclăuş), and in the foothill fields (5-15 $\mathrm{m}$ deep), where they manifest themselves as springs, locusts and even shrubs (Ierului Plain). Groundwaters and downstream captive waters $(15-20 \mathrm{~m})$ in fluvial-lake formations (sands) are used to supply drinking water for Satu Mare and Carei municipalities and their surrounding areas, but which can suffer certain infiltrations likely to cause groundwater contamination.

\section{CONCLUSIONS AND FINDINGS}

Following the spatio-temporal analysis of the triggering factors involved in the formation of the water surplus, it is worth mentioning that as far as the Plain of Somes is concerned, under natural conditions, the general character of the natural landscape was due to the presence of wetlands with hydrophilic vegetation and extended oak forests. However, following the anthropogenic interventions carried out over time, these occur only in the form of clusters, and the eutrophic marshes and the meadow vegetation have almost disappeared, yet there are clear traces of 
hydrophilic adaptability among them as a result of the water excess in the soil where it is retained.

Nowadays, the landscape of the Plain of Somes is given by agricultural crops, the arable lands representing the dominant form of land use, pastures and natural grasslands, covering only the fields with lower fertility, and the ones with humidity excess being a potential factor in determining the water surplus, and hence - agricultural damage.

\section{REFERENCES}

1. Bătinaş, R., Sorocovschi, V., Şerban, Gh. (2002), Fenomene hidrologice de risc induse de viituri in bazinul inferior al Arieşului, Seminarul Geografic Dimitrie Cantemir, Iaşi.

2. Sorocovschi, V. (2005), Riscuri și catastrofe, Casa Cărții de Știință, Cluj Napoca.

3. Sorocovschi, V., Șerban, Gh. (2008), Hidrogeologie. Edit. Casa Cărții de Știință, Cluj Napoca.

4. Bătinaș, R., Sanislai, D. (2012), Some aspects regarding the flood waves analysis at Satu Mare Hydrometric Station on the Someș River. Conferința anuală: "Aerul și Apa, componente ale mediului", Universitatea "Babeș-Bolyai", Facultatea de Geografie, Cluj Napoca, 23-24 Martie 2012, Cluj Napoca;

5. Sanislai, D., Bătinaș, R. (2012), Some aspects regarding the flash flood analysis and the natural flood risk map of Someș Plain. Revista "Riscuri și Catastrofe". Centrul de Cercetare a Hazardelor și Riscurilor Geografice. Universitatea "BabeșBolyai", Facultatea de Geografie, Cluj Napoca;

6. *** (2010), Planul de management bazinal Someş-Tisa, Direcţia de Ape SomeşTisa, filială teritorială în cadrul Administraţiei Naţionale Apele Române.

7. *** (2005), Regulamentul privind gestionarea situaţiilor de urgentă generate de inundații, fenomene meteorologice periculoase, accidente la construcţii hidrotehnice şi poluări accidentale, Ordin 638/2005 al Ministerului Administraţiei şi Internelor, respectiv 420/2005 al Ministerului Mediului şi Gospodăririi Apelor, Monitorul Oficial 455 din 30 mai 2005.

8. *** (2004), Ordonanţa de urgenţă privind Sistemul Naţional de Management al Situaţiilor de Urgență, O.U. nr. 21/2004 din 15/04/2004, Monitorul Oficial, Partea I nr. 361 din 26 aprilie 2004.

9. *** Hydrological data recorded at Satu Mare hydrometric station, ABA SomeşTisa, $1974-2004$.

10. $* * *$ LEGE privind evaluarea și managementul inundațiilor din 2006-05-04.

11. *** Memoriu privind planul de apărare împotriva inundaţiilor, fenomenelor meteorologice periculoase şi accidentelor la construcţiile hidrotehnice al Comitetului Județean pentru Situaţii de Urgenţă Satu Mare 2010-2013. 